\title{
Thyroid hormones in the regulation of brown adipose tissue thermogenesis
}

\author{
Sarah Christine Sentis, Rebecca Oelkrug and Jens Mittag \\ Institute for Endocrinology and Diabetes, Center of Brain, Behavior and Metabolism (CBBM), University of Lübeck, Lübeck, Germany
}

Correspondence should be addressed to J Mittag: jens.mittag@uni-luebeck.de

\begin{abstract}
A normal thyroid status is crucial for body temperature homeostasis, as thyroid hormone regulates both heat loss and conservation as well as heat production in the thermogenic tissues. Brown adipose tissue (BAT) is the major site of non-shivering thermogenesis and an important target of thyroid hormone action. Thyroid hormone not only regulates the tissue's sensitivity to sympathetic stimulation by norepinephrine but also the expression of uncoupling protein 1, the key driver of BAT thermogenesis. Vice versa, sympathetic stimulation of BAT triggers the expression of deiodinase type II, an enzyme that enhances local thyroid hormone availability and signaling. This review summarizes the current knowledge on how thyroid hormone controls BAT thermogenesis, aiming to dissect the direct actions of the hormone in BAT and its indirect actions via the CNS, browning of white adipose tissue or heat loss over body surfaces. Of particular relevance is the apparent dose dependency of the observed effects, as we find that minor or moderate changes in thyroid hormone levels often have different effects as compared to high pharmacological doses. Moreover, we conclude that the more recent findings require a reevaluation of older studies, as key aspects such as heat loss or central BAT activation may not have received the necessary attention during the interpretation of these early findings. Finally, we provide a list of what we believe are the most relevant questions in the field that to date are still enigmatic and require further studies.

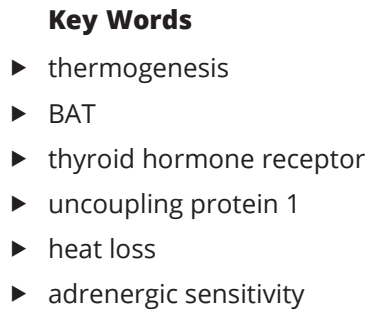

Key Words

thermogenesis

$\rightarrow$ BAT

- thyroid hormone receptor

- uncoupling protein

- adrenergic sensitivity

Endocrine Connections (2021) 10, R106-R115
\end{abstract}

\section{Introduction}

The maintenance of body temperature according to a central set point is crucial for several physiological processes and largely regulated by balancing heat production as well as heat dissipation. Particularly the latter process is of great relevance in humans, which possess a large surface area that unlike in rodents is only sparsely covered with fur or hair. Therefore, vasodilation is an important response to dissipate excess heat, that is, during physical exercise, and vasoconstriction often occurs to conserve heat, that is, during cold exposure. Simultaneously, heat production processes are regulated accordingly, most prominently the induction of shivering in cold environments. However, also other means can significantly contribute to maintain body temperature including behavioral changes such as moving less in the heat or cuddling in the cold (1).

In the past decade, a special research focus has been put on the mechanisms underlying heat generation, as these processes could theoretically be used to fight obesity and metabolic disorders by burning excess calories. In humans, skeletal muscle is the primary thermogenic tissue, capable of providing rapid heat by shivering. However, in small mammals and newborn humans, the specialized brown adipose tissue (BAT) is the main thermogenic organ, providing a more long-lasting and sustainable source of converting stored energy into heat via non-shivering thermogenesis (2). Thus, BAT constitutes a potential 
anti-obesity drug target, especially as it was recently also identified in adult humans (3).

BAT thermogenesis is mainly mediated by the uncoupling protein 1 (UCP1) $(4,5)$, a transmembrane protein with six $\alpha$-helical domains, which possesses a single substrate binding site a proton binding site, and several hydrophobic residues $(5,6,7)$. The highest amount of this protein is located in the inner mitochondrial membrane of brown adipocytes, where, upon activation by free fatty acids, it drives the uncoupling of oxidative phosphorylation from ATP production by operating as proton carrier (8). The energy produced by the oxidation of substrates is thus released as heat giving BAT its thermogenic features. Under normal conditions, BAT is activated by the release of norepinephrine (NE) from the nerve terminals of the sympathetic nervous system (SNS). In response to NE-binding, $\beta$-adrenergic receptors facilitate second messenger signaling including the increase of intracellular cAMP concentrations and subsequently the stimulation of protein kinase A activity (Fig. 1A). While in the activation of rodent thermogenesis, the $\beta 3$ adrenergic receptor plays the predominant role with a possible potentiating effect of $\alpha 1$ adrenergic receptors, recent findings suggested that in humans the $\beta 2$ isoform might be more relevant $(9,10)$. The downstream targets of the adrenergic receptors in both species, however, include for example, the hormone-sensitive lipase, which provides free fatty acids after breaking down triacylglycerols, and CREB, which activates gene expression (11).

An important regulator of BAT thermogenesis is thyroid hormone (TH), which is well-known for its effects on body temperature. Hyperthyroid patients, for instance, display an elevated body temperature and are sensitive to heat, while hypothyroid patients exhibit problems to maintain their body temperature and often feel cold (12). This review aims to summarize the current knowledge on how TH interacts with the different pathways important for maintaining body temperature with a special focus on BAT function.

\section{Impaired thyroid hormone action interferes with correct BAT function}

It is long known from early studies in thyroidectomized rats that TH is required for proper BAT function (13). On the molecular level, this comes down to two major effects, namely regulating $U c p 1$ transcription and controlling the sensitivity of BAT to NE (14). The latter is of particular importance, as NE increases type II deiodinase (DIO2) activity leading to an augmented intracellular conversion of the biologically less active thyroxin (T4) to the receptoractive form 3,3',5-triiodothyronine (T3) by removing an iodine from the outer ring, thus constituting an important feed forward stimulation within the tissue. This complex synergistic interplay between the direct actions of TH in BAT, the local generation of $\mathrm{T} 3$ and the central stimulation of BAT by NE lies at the heart of understanding TH action in BAT thermogenesis (15).

\section{Regulation of Ucp1 gene expression}

The regulation of UCP1 content in BAT mitochondria by TH has been established long ago by studies showing lower UCP1 in rats made hypothyroid through thyroidectomy $(16,17,18)$. Most remarkably, Ucp1 expression in these animals could not even be upregulated when the rats were exposed to cold, which is usually a very strong stimulus for their thermogenic response $(17,19,20)$. This clearly demonstrates that $\mathrm{TH}$ signaling is absolutely required for Ucp1 induction and cannot be compensated by increased sympathetic stimulation of BAT. Vice versa, TH treatment by itself is also not sufficient to induce Ucp1 mRNA or protein at $23^{\circ} \mathrm{C}$ or $10^{\circ} \mathrm{C}$ ambient temperature as compared to untreated controls $(21,22)$. Interestingly, however, T3 treatment was found to induce Ucp 1 mRNA and UCP1 protein in mice kept at thermoneutrality - a condition with minimal NE stimulation of BAT thermogenesis (22), indicating that there may be conditions under which the hormone alone can trigger $U c p 1$ expression. Nevertheless, due to the lack of sympathetic input in mice at $30^{\circ} \mathrm{C}$, the baseline levels of $U c p 1$ are extremely low to begin with, and $\mathrm{T} 3$ treatment did not restore the UCP1 levels in those animals to the amounts present at room temperature.

Taken together, these findings underline that the individual responses of $U c p 1$ to $\mathrm{NE}$ or $\mathrm{T} 3$ alone are rather small and that only the combined synergistic actions of both factors can efficiently induce Ucp1 expression.

\section{Local T3 production by DIO2 in BAT}

Molecular studies revealed that Ucp1 gene expression induced by T3 occurs via TH-response elements (TRE) located in the $5^{\prime}$-flanking region of Ucp1 (23). For a maximal response, the saturation of thyroid hormone receptors (TRs) with T3 seems to be required, which is physiologically achieved by a bulk conversion of $\mathrm{T} 4$ to T3 within the BAT by DIO2 $(16,17,19)$. Therefore, the intracellular production of receptor-active $\mathrm{T} 3$ is a key event in the thermogenic response of BAT. Upon NE-stimulation, the downstream cAMP signaling 
A

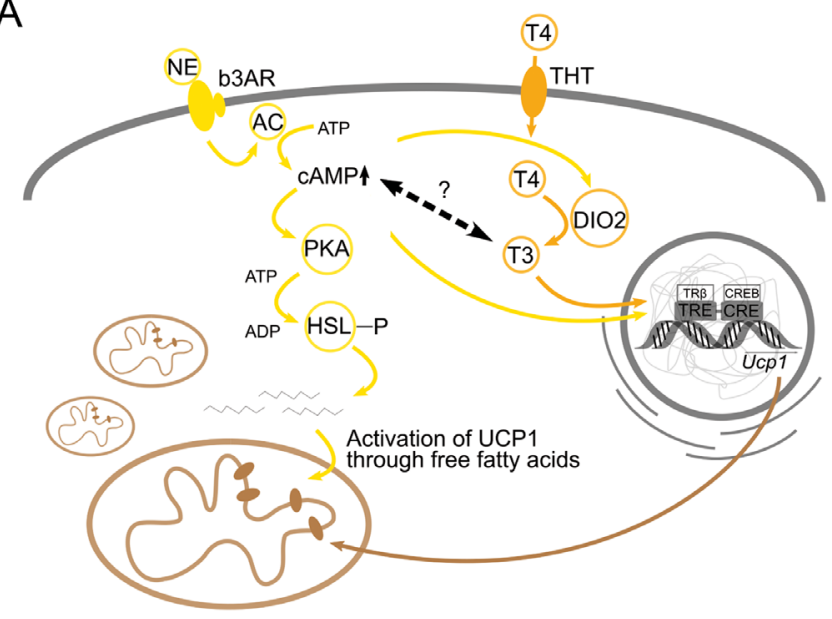

B
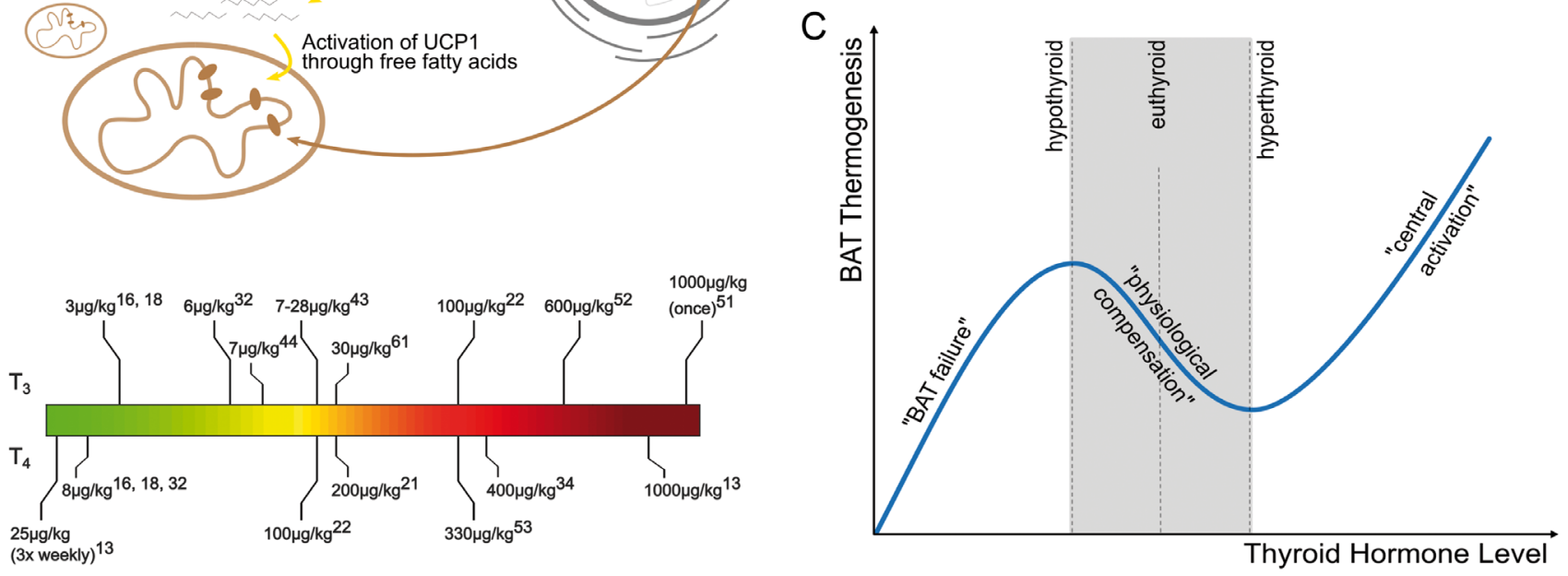

Figure 1

(A) Schematic overview of the crosstalk between sympathetic and thyroid hormone signaling in a brown adipocyte. AC, adenylate cyclase; b3AR, beta 3 adrenergic receptor; DIO2, type II deiodinase; HSL, hormone sensitive lipase; NE, norepinephrine; PKA, protein kinase A; THT, thyroid hormone transporter; T3, 3,3',5-triiodothyronine; T4, thyroxine; TRE, thyroid hormone response element. (B) Overview of thyroid hormone treatments used in different studies assessing its effects on brown adipose tissue. If not otherwise noted, the daily dose for duration of experiment is given. Uppercase numbers indicate the respective reference. (C) Proposed dependence of brown fat thermogenesis on thyroid hormone levels. During mild hypo- or hyperthyroidism, brown fat thermogenesis is adjusted to compensate for the change in obligatory thermogenesis and/or heat loss. In strong hypothyroidism, brown fat function fails entirely. In strong hyperthyroidism, the central T3 action dominates over the physiological adaptation and causes brown fact activation.

cascades strongly increase DIO2 activity leading to a three- to four-fold elevation of $\mathrm{T} 3$ concentration resulting in saturation of the nuclear TRs and the full induction of BAT thermogenesis (24). This was first observed in studies with thyroidectomized rats, which showed a normal cold response including an appropriate upregulation of Ucp1 after the application of T4, but not T3, suggesting that the local conversion of $\mathrm{T} 4$ by $\mathrm{DIO} 2$ is required for saturation of TRs $(16,19,25)$. This was later confirmed in Dio2 knockout (D2KO) mice, which, despite normal T3 and even elevated $\mathrm{T} 4$ serum levels, exhibit an impaired BAT function and their ability to properly react to cold exposure is reduced and results in hypothermia $(25,26)$. Additionally, D2KO mice display impaired lipolysis and lipogenesis, which additionally affects UCP1-mediated respiratory uncoupling and thermogenesis, as activation of this protein greatly depends on the availability of free fatty acids $(25,27,28)$. In line with these in vivo experiments, isolated brown adipocytes treated with the DIO2 inhibitor iopanoic acid showed diminished induction of $U c p 1$ gene expression $(29,30)$.

\section{Interactions of NE and TH signaling in BAT}

A key regulator of BAT thermogenesis is sympathetic signaling, which mediates the central regulation of body temperature by releasing $\mathrm{NE}$ from the nerve terminals. This $\mathrm{NE}$ release is crucially required for the TH effects on BAT, as it provides for example, the intracellular DIO2 upregulation needed for full activation of TRs. Consequently, TH alone cannot trigger $U c p 1$ upregulation in hypothyroid rats in the absence of sympathetic stimulation (17). On the molecular level, it is assumed that the increase of intracellular cAMP levels upon NE-binding is required to active nuclear CREB (Fig. 1A), which in turn allows TREs to drive the upregulation of $U c p 1$ (31). 
Vice versa, a thermogenic response to NE cannot be sufficiently induced in thyroidectomized rats even if sufficient UCP1 protein is available, suggesting that TH also affects other mechanisms potentially including intracellular UCP1 translocation or activation by free fatty acids (32). Likewise, it was observed in cultured rat brown adipocytes that the response to different NE stimulations depends on the availability of TH (15). These findings clearly suggest that TH somehow also modulates the thermogenic response of BAT to NE, presumably by affecting the adrenergic signaling pathway downstream of the respective receptors. It is, however, still controversial to date in how far $\mathrm{TH}$ also directly affects NE-turnover in BAT upstream of the receptor. Some studies did not find any change in hyperor hypothyroid rats (33), while others showed increased NE during hypothyroid conditions (34). This would be in line with the reasoning that the tissue aims to partly compensate for missing circulating $\mathrm{TH}$ by upregulating DIO2 for increased local conversion of T4 to T3 $(35,36)$.

\section{Divergent pathways for NE sensitivity and Ucp1 expression}

Interestingly, thyroidectomized rats rescued with twice the physiological replacement dose of T3 showed a normal thermal response to NE infusion, despite the fact that their UCP1 protein content had not been normalized (32). In contrast, thyroidectomized rats treated with physiological T4 replacement doses had normalized adrenergic responsiveness of BAT and normalized Ucp1 mRNA content $(32,37)$. While the duration of the treatment might be a crucial factor contributing to these divergent effects, the findings still suggest that serum T3 might primarily affect NE responsiveness, while the locally produced T3 by DIO2 might be more effectively and more rapidly regulating Ucp1 expression.

Unfortunately, to date little is known on the precise mechanisms that mediate TH's effects on NE responsiveness. While some early studies showed that TH stimulates the expression of $\beta$-adrenergic receptors in BAT (34), more recent studies found the opposite, namely reduced expression of $A d r b 3$ at $23^{\circ} \mathrm{C}$ (22). As this effect was also observed at $10^{\circ} \mathrm{C}$ and $30^{\circ} \mathrm{C}$, temperatures with higher and lower sympathetic input to BAT, it seems to be a direct $\mathrm{T} 3$ effect independent of NE input. In line with these findings, an increased expression of $A r d b 3$ was observed in mice and rats with hypothyroidism $(34,38)$. It is tempting to speculate that these changes in $A d r b 3$ serve as a local physiological feedback mechanism to reduce BAT sensitivity to NE in hyperthyroidism, where the animals exhibit excess heat production due to an elevated metabolic rate $(22,39)$, or to increase NE action in hypothyroidism, a period in which the animals might need additional facultative thermogenesis.

\section{Thyroid hormone receptors in BAT}

Two main types of nuclear TRs mediate the different functions of TH, TR $\alpha 1$ and TR $\beta$. Both receptors act as liganddependent transcription factors but display a tissue-specific distribution across the body. Although TR $\alpha 1$ and TR $\beta$ are never fully mutually exclusive, TR $\alpha 1$ is mostly located in the heart and in the brain, while TR $\beta$ isoforms play a major role in the hypothalamus-pituitary-thyroid axis, the liver, and inner ear development $(40,41)$. However, whether the individual contributions of each receptor isoform in various tissues and organs rely primarily on their expression levels or if there are isoform specific regulatory mechanisms is not yet fully elucidated. Brown adipocytes accommodate both TR $\alpha 1$ and TR $\beta$ nuclear receptors (42). However, it was only in the late 90s, when the TR $\beta$-selective analog, GC-1, opened the door to identify isoform specific functions in BAT, as the compound binds to TR $\beta$ equally well as T3 but has a ten-fold reduced affinity to TR $\alpha 1$. This effect was used in a study from 2001, revealing that diet-induced hypothyroid rats treated with GC-1 restored Ucp1 expression in brown adipocytes but failed to normalize the thermal response of BAT to NE (43). This TR $\beta$ isoform dependence of Ucp1 expression in BAT was later confirmed in TR $\beta$ knockout animals (43, 44). However, more recent studies did not find altered Ucp1 expression levels and UCP1 protein in TR $\beta$ knockout mice in comparison to wildtype animals (22), suggesting that TR $\alpha 1$ might be able to partially compensate the loss of TR $\beta$ under specific conditions. The importance of TR $\alpha 1$ signaling for the adrenergic sensitivity of BAT, however, was supported by findings in several different animal models. Mice lacking all TR $\alpha$ gene products have a blunted response to BAT stimulation by $\mathrm{NE}(45)$, and TR $\alpha 1$ mutant mice kept at $30^{\circ} \mathrm{C}$ showed no response to NE at all (46); however, for the latter study it needs to be kept in mind that the overall response to $\mathrm{NE}$ is generally reduced at $30^{\circ} \mathrm{C}$, even in wildtypes.

\section{Effects of increased TH action on BAT}

Studies on the regulation of UCP1 and BAT thermogenesis by TH were made over an extremely broad range of treatment conditions (Fig. 1B), which makes the comparison of the results quite complicated. Moreover, most experiments were

This work is licensed under a Creative Commons Attribution-NonCommercial-NoDerivatives 4.0 enternationad License.ifica. com at 04/26/2023 01:29:42PM 
conducted in animal models that reflected the transition from severe hypothyroidism to hyperthyroidism, which, despite being a solid model system, has little relevance in humans. Therefore, researchers also used model systems, which resembled the development of hyperthyroidism from an euthyroid starting point. These studies revealed that, in contrast to hypothyroid animals indicating an enhanced sympathetic tone in BAT, hyperthyroid animals display a reduced adrenergic responsiveness in BAT (47, $48,49,50)$. As this correlation acts in parallel with the requirement of $\mathrm{TH}$ for the NE-mediated induction of UCP1, the overall TH modulated thermogenic activity of BAT was thought to resemble an inverse U-shaped curve with its maximum roughly within the euthyroid range (50). This model was then refined by studies in hyperthyroid animals with moderate T4 doses $(<200 \mu \mathrm{g} / \mathrm{kg}$ per day), which lead to an elevated body temperature after 2 weeks of T4 treatment, but no changes in interscapular BAT (iBAT) thermogenesis, revealed by IR thermography. Furthermore, UCP1 protein levels were not altered, but Ucp 1 mRNA expression was decreased (21), suggesting that iBAT was on the verge of being turned down. This trend was continued in mice treated with $\mathrm{T} 3$, which reached a higher level of hyperthyroidism, where BAT was in fact less active in IR thermography, PET-CT scans, and lipid uptake assays (22). However, when the treatment regimen reaches high pharmacological doses of T4 (>600-1000 $\mu \mathrm{g} / \mathrm{kg}$ per day) over a period of 4-5 weeks, this physiological downregulation of iBAT thermogenesis is overridden. Here, an increased NE response, both at thermoneutrality as well as during cold exposure, was observed (51). Likewise, increased Ucp1 mRNA content in BAT was also observed in mice with orally administered T3 $(\sim 600 \mu \mathrm{g} / \mathrm{kg}$ per day) at room temperature (52).

Taken together, it can be concluded that the extent of hypo- or hyperthyroidism has a severe effect on BAT function. Mild hypothyroidism will cause an increased sympathetic tone, which can activate BAT for compensation of reduced obligatory thermogenesis and elevated heat loss; however, when hypothyroidism becomes more severe, BAT function collapses. Likewise, mild to moderate hyperthyroidism will cause a reduction in BAT activity, presumably because the overall increase in metabolism elevates obligatory thermogenesis and thereby reduces the need for facultative thermogenesis in BAT. However, when hyperthyroidism reaches excessive levels, BAT becomes activated again (Fig. 1C) - a puzzling conundrum that can probably be explained by the central actions of $\mathrm{TH}$ in the brain and on the body temperature set point.

\section{Central effects of TH}

Besides the direct actions of TH on peripheral organs such as liver, heart, and BAT, TH may also provoke central actions indirectly mediating peripheral alterations. A first hypothesis, the altered set point hypothesis by Nedergaard et al. in 1997, proposed that the body temperature set point is centrally regulated and influenced by $\mathrm{TH}$ (51). More recently, López et al. presented findings on the interplay of the SNS and BAT thermogenesis upon central intracerebroventricular administration of $\mathrm{T} 3$ in rats. T3 decreases levels of the AMP-activated protein kinase in the ventromedial hypothalamus (VMH), which in turn increases SNS activity stimulating BAT thermogenesis. Additionally, thermogenic markers, such as Ucp1, hormone sensitive lipase, and Dio2 are upregulated in BAT, leading to an increased thermogenic capacity of BAT as a consequence of central T3 administration $(53,54)$. More importantly, body temperature was also raised, an effect that was not observed in mice lacking UCP1, demonstrating that BAT is the primary driver of body temperature elevation induced by central T3 $(55,56)$. While this was found to be dependent on TR $\alpha 1$, other studies observed an important role of TR $\beta$ in the VMH in this context, although BAT function specifically was not studied in great detail (57). However, given that TR $\alpha 1$ is the predominant isoform in neurons (58) and the levels of hypothalamic TR $\beta$ protein are low (59), the precise contribution of TR $\beta$ to the central control of BAT thermogenesis remains yet to be established in this context.

That central T3 action is crucial for body temperature regulation was recently confirmed in a study employing MCT8 and OATP1C1 double knockout mice. These animals lack two transporters required for the uptake of TH into the brain, with the consequence that their brains are severely hypothyroid (60). Despite their peripherally elevated T3 levels, these animals did not show an elevated body temperature (61), demonstrating that this classic feature of hyperthyroidism indeed requires the central actions of $\mathrm{TH}$.

However, the connection between centrally acting T3 and its effects on peripheral organs might still be more complex. Ucp1 knockout mice treated systemically with T3 or T4 did in fact show an elevated body temperature $(22,62)$, suggesting that the body temperature elevation in hyperthyroidism does not depend on active BAT thermogenesis. More importantly, the authors showed that T3 treated mice had elevated heat loss over the tail, suggesting that the animals actually needed to dissipate heat to maintain the body temperature, indicative of

This work is licensed under a Creative Commons Attribution-NonCommercial-NoDerivatives 4.0 International License ifica com at $04 / 26 / 2023$ 01:29:42PM 
excess heat production in the periphery, presumably the muscle (22). Interestingly, however, it was also shown that blocking TR $\alpha 1$ signaling exclusively in the muscle also does not interfere with the elevation of body temperature upon thyroid hormone treatment (63).

Collectively, these data suggest that $\mathrm{T} 3$ acts in the brain to elevate the body temperature set point. Under normal conditions, the simultaneous action of $\mathrm{T} 3$ in the muscle suffices to meet this new set point - and under certain conditions even beyond, as the T3 treated mice dissipated excess heat (22). However, if a thermogenic impairment occurs such as lack of UCP1 in BAT or defective TR $\alpha 1$ in muscle, other mechanisms seem to be activated to achieve the body temperature elevation.

\section{Open questions}

After decades of research involving $\mathrm{TH}$ and its regulatory role in BAT and subsequently on BAT thermogenesis, a lot has been learnt on the underlying mechanisms, ranging from actions in muscle, white adipose tissue and BAT for thermogenesis over tail heat loss to central adjustments of thermoregulation and behavior (Fig. 2). However, the complex interplay of $\mathrm{TH}$ with all these systems and their interactions among each other is far from being understood. Many open questions remain to be addressed in this area, especially with the connections to other systemic effects induced by TH.

\section{What is the reason for different body weight} phenotypes during hyperthyroidism in mice, rats, and humans?

A current paradox in the field is the different body weight phenotypes in rats, mice, and humans in hyperthyroidism. Hyperthyroid rats and humans are metabolically more active leading to a reduction of body weight, whereas hyperthyroid mice gain weight over time despite an elevated body temperature and higher metabolic demands $(36,62,64,65)$. Similarly, hypothyroid mice develop a leaner phenotype than euthyroid controls, although energy expenditure and overall daily activity are significantly reduced. A recent study suggested that mouse hypothyroidism triggers an upregulation of different markers involved in skeletal muscle-mediated adaptive thermogenesis, as well as the upregulation of fatty acid oxidation to compensate for the well-established cold intolerance of hypothyroid mice (64). However, it remains to be seen whether this thermogenic effect in muscle is maintained at more severe degrees of hypothyroidism, as BAT thermogenesis is also stimulated in mild hypothyroidism, or fails at more severe conditions (see earlier). To solve this conundrum more studies comparing rats and mice at different $\mathrm{TH}$ levels are urgently needed, especially when considering that primary brown adipocytes of both species also respond differently with regard to Ucp1 mRNA expression (66).

\section{What are the precise contributions of the central and peripheral TH effects for BAT thermogenesis and body temperature regulation?}

However, to date the most striking enigma evolves around the contribution of TH on central and peripheral actions, and in particular, the dose, treatment duration, and temperature dependency of both effects. Severe hyperthyroidism induced by high doses of T3 recruits BAT via increased UCP1 protein and enhances the thermogenic capacity of BAT $(54,55)$; however, low to moderate doses of T3 or T4 do not seem to have this effect on BAT thermogenesis (21, 22). Nevertheless, central TH actions are absolutely required to increase body temperature (61). Consequently, further experiments aiming at dissecting central and peripheral (direct BAT) effects in a dose- and time-dependent manner are urgently required to address this conundrum.

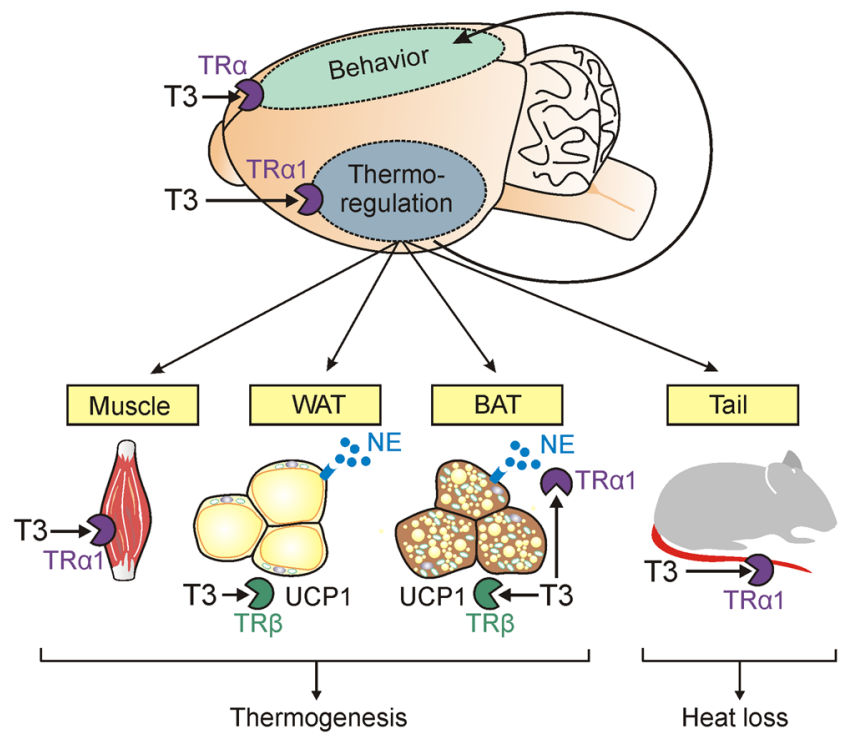

Figure 2

Schematic representation of the different systems regulating body temperature that are affected by thyroid hormone action. BAT, brown adipose tissue; NE, norepinephrine; TR $\alpha 1$, thyroid hormone receptor $\alpha 1$; TR $\beta$, thyroid hormone receptor $\beta ;$ T3, 3,3',5-triiodothyronine; UCP1, uncoupling protein 1; WAT, white adipose tissue.

his work is licensed under a Creative Commons Attribution-NonCommercial-NoDerivatives 4.0 International License ifica $_{\text {com }}$ at $04 / 26 / 2023$ 01:20:42PM 
What do Ucp1 expression levels and UCP1 protein tell us about the thermogenic capacity of BAT?

With the discovery of UCP1 in the 1980s and the subsequent connection to BAT thermogenesis, Ucp1 expression and UCP1 protein are normally used to describe the thermogenic capacity of BAT while the responsiveness of BAT to NE is less often discussed. However, Ucp1 mRNA and sometimes even UCP1 protein abundance can be insufficient to describe the real thermogenesis (67). Particularly, in the response to $\mathrm{TH}$, these parameters can often be discordant $(22,61)$. It is therefore highly recommended to provide physiological data, for example, IR thermography or energy expenditure also in response to $\mathrm{NE}$, in addition to the molecular data. If needed, the latter could in addition to Ucp1/UCP1 include intracellular cAMP levels, histology, proteins of the oxidative phosphorylation chain, or even NE-turnover measurements (22) to provide a more complete picture on the state of BAT thermogenesis. As these data are largely missing for many of the older studies (for obvious technical reasons), reevaluation of seemingly established concepts might be necessary.

\section{When does 'browning' of WAT contribute to thermogenesis or energy expenditure?}

Since BAT and its thermogenic capacity is often discussed in the context of obesity and as a possible target to assist with weight loss or to lower the risk for cardiovascular diseases and diabetes type II, it is of high interest if white adipose tissue (WAT) can be triggered to gain brown fat features - a process called 'browning'. Browning of WAT is usually associated with greater amounts of mitochondria and increased levels of Ucp 1 expression and UCP1 protein, which theoretically implies an enhanced thermogenic capacity. In the context of TH research, browning was observed in several studies $(34,56,68)$. However, recent data suggested that, at least with T3, browned WAT is metabolically not active (22). Nevertheless, given that a more specific activation, by only targeting TR $\beta$, evoked metabolic benefits (68), presumably due to the lack of parallel TR $\alpha 1$ activation in brain and muscle, there may still be some value in targeting TH signaling in WAT.

\section{Which peripheral tissue mediates the increase in} body temperature in response to hyperthyroidism?

In the light of the recent studies, it seems plausible that $\mathrm{TH}$ primarily elevates body temperature by increasing the central set point as in pyrexia $(22,62)$, which is at least partially fueled by peripheral $\mathrm{TH}$ action in muscle (22,
39). However, the higher body temperature is observed in conditions with inactive BAT or browned WAT including Ucp1 knockout mice $(22,62)$, as well as in mice with blocked skeletal muscle TR $\alpha 1$ signaling (63), which suggests that neither BAT nor muscle are absolutely required for the effect but likely can compensate for each other. Interestingly, alternative and UCP1-independent mechanisms of BAT thermogenesis could play a role in this context (69, 70); however, these pathways were not upregulated in hyperthyroid mice (22). Alternatively, one could speculate that under these rather pathological conditions, other mechanisms are recruited to defend the elevated body temperature, including reduced conductance or altered behavior (39). Additional carefully designed studies will be required to dissect the individual contributions.

\section{What are the contributions of heat dissipation via the tail for adjusting facultative thermogenesis mediated by BAT?}

The vast majority of studies on $\mathrm{TH}$ and body temperature regulation have exclusively been looking at thermogenesis. However, a recent study has shown that $\mathrm{TH}$ is also important for tail artery function, which regulates heat dissipation over the tail surface (71). If tail vasoconstriction is impaired, as seen in defective TR $\alpha 1$ signaling, heat is lost and additional thermogenesis is initiated to defend body temperature. This clearly demonstrates that BAT activation can occur as a secondary consequence of heat conductance defect, which is not only restricted to defective vasoconstriction but could also include fur properties, breathing rate, or behavioral changes (72). Again, these contributing factors have not been taken into consideration in previous studies, which may therefore require reevaluation of established concepts.

\section{Take home message}

Despite decades of TH research that unveiled the highly regulated interactive triangle of TH action, NE sensitivity and BAT thermogenesis, several aspects in this context are still incompletely understood. Although we know that TH and NE signaling alone are insufficient to induce UCP1-mediated thermogenesis and only the synergy of both stimuli provides an adequate BAT effect, the doseand time-dependent contributions of both factors remain to be investigated. More recent research additionally complicated the regulatory mechanisms by revealing that central actions of TH also influence BAT thermogenesis

This work is licensed under a Creative Commons Attribution-NonCommercial-NoDerivatives 4.0 Internationad bicense.ifica.com at 04/26/2023 01:29:42PM 
and moreover the body temperature set point, which in turn leads to secondary thermoregulatory adaptations in several systems. This includes, for instance, the adjustment of heat loss, for example, via vasoconstriction over the tail surface in mice, which has rarely been documented in previous studies. Consequently, further studies aiming to investigate the effects of $\mathrm{TH}$ on body temperature regulation are urgently required and should consider the most recent findings on centrally acting THs and their influence on tail vasoconstriction to provide a complete picture of the thermoregulatory pathways affected by $\mathrm{TH}$.

\section{Declaration of interest}

The authors declare that there is no conflict of interest that could be perceived as prejudicing the impartiality of this review.

\section{Funding}

This work was funded by the Deutsche Forschungsgemeinschaft DFG within the framework of the SPP1629 'Thyroid TransAct', the GRK1957 'Adipocyte-Brain-Crosstalk', the CRC/TR296 'Local Control of Thyroid Hormone Action', as well as the grants Mi1242/9-1 and OE723/2-1, and the Medical Faculty of the University of Lübeck (14-2018).

\section{References}

1 Gordon CJ. Thermal biology of the laboratory rat. Physiology and Behavior 199047 963-991. (https://doi.org/10.1016/00319384(90)90025-Y)

2 Virtanen KA, Lidell ME, Orava J, Heglind M, Westergren R, Niemi T, Taittonen M, Laine J, Savisto NJ, Enerbäck S, et al. Functional brown adipose tissue in healthy adults. New England Journal of Medicine 2009 360 1518-1525. (https://doi.org/10.1056/NEJMoa0808949)

3 Frühbeck G, Becerril S, Sáinz N, Garrastachu P \& GarcíaVelloso MJ. BAT: a new target for human obesity? Trends in Pharmacological Sciences 200930 387-396. (https://doi.org/10.1016/j. tips.2009.05.003)

4 Jacobsson A, Stadler U, Glotzer MA \& Kozak LP. Mitochondrial uncoupling protein from mouse brown fat. Molecular cloning, genetic mapping, and mRNA expression. Journal of Biological Chemistry 1985 260 16250-16254. (https://doi.org/10.1016/S0021-9258(17)36228-2)

5 Kozak LP, Britton JH, Kozak UC \& Wells JM. The mitochondrial uncoupling protein gene. Correlation of exon structure to transmembrane domains. Journal of Biological Chemistry 1988263 12274-12277. (https://doi.org/10.1016/S0021-9258(18)37751-2)

6 Ricquier D, Casteilla L \& Bouillaud F. Molecular studies of the uncoupling protein. FASEB Journal 19915 2237-2242. (https://doi. org/10.1096/fasebj.5.9.1860614)

7 Ricquier D. UCP1, the mitochondrial uncoupling protein of brown adipocyte: a personal contribution and a historical perspective. Biochimie 2017 134 3-8. (https://doi.org/10.1016/j. biochi.2016.10.018)

8 Fedorenko A, Lishko PV \& Kirichok Y. Mechanism of fatty-aciddependent UCP1 uncoupling in brown fat mitochondria. Cell 2012 151 400-413. (https://doi.org/10.1016/j.cell.2012.09.010)

9 Blondin DP, Nielsen S, Kuipers EN, Severinsen MC, Jensen VH, Miard S, Jespersen NZ, Kooijman S, Boon MR, Fortin M, et al. Human brown adipocyte thermogenesis is driven by $\beta 2$-AR stimulation. Cell Metabolism 202032 287.e7-300.e7. (https://doi.org/10.1016/j.cmet.2020.07.005)

10 Zhao J, Cannon B \& Nedergaard J. $\otimes 1$-adrenergic stimulation potentiates the thermogenic action of $\beta 3$-adrenoreceptor-generated cAMP in brown fat cells. Journal of Biological Chemistry 1997272 32847-32856. (https://doi.org/10.1074/jbc.272.52.32847)

11 Cannon B \& Nedergaard J. Brown adipose tissue: function and physiological significance. Physiological Reviews 200484 277-359. (https://doi.org/10.1152/physrev.00015.2003)

12 Chaker L, Bianco AC, Jonklaas J \& Peeters RP. Hypothyroidism. Lancet 2017390 1550-1562. (https://doi.org/10.1016/S01406736(17)30703-1)

13 Triandafillou J, Gwilliam C \& Himms-Hagen J. Role of thyroid hormone in cold-induced changes in rat brown adipose tissue mitochondria. Canadian Journal of Biochemistry 198260 530-537. (https://doi.org/10.1139/o82-065)

14 Bianco AC \& McAninch EA. The role of thyroid hormone and brown adipose tissue in energy homoeostasis. Lancet Diabetes and Endocrinology 20131 250-258. (https://doi.org/10.1016/S22138587(13)70069-X)

15 Hernández A \& Obregón MJ. Triiodothyronine amplifies the adrenergic stimulation of uncoupling protein expression in rat brown adipocytes. American Journal of Physiology: Endocrinology and Metabolism 2000278 E769-E777. (https://doi.org/10.1152/ ajpendo.2000.278.5.E769)

16 Bianco AC \& Silva JE. Optimal response of key enzymes and uncoupling protein to cold in BAT depends on local T3 generation. American Journal of Physiology 1987253 E255-E263. (https://doi. org/10.1152/ajpendo.1987.253.3.E255)

17 Bianco AC \& Silva JE. Cold exposure rapidly induces virtual saturation of brown adipose tissue nuclear T3 receptors. American Journal of Physiology 1988255 E496-E503. (https://doi.org/10.1152/ ajpendo.1988.255.4.E496)

18 Carvalho SD, Kimura ET, Bianco AC \& Silva JE. Central role of brown adipose tissue thyroxine 5 -deiodinase on thyroid-hormonedependent thermogenic response to cold. Endocrinology 1991128 2149-2159. (https://doi.org/10.1210/endo-128-4-2149)

19 Bianco AC \& Silva JE. Intracellular conversion of thyroxine to triiodothyronine is required for the optimal thermogenic function of brown adipose tissue. Journal of Clinical Investigation $1987 \mathbf{7 9}$ 295-300. (https://doi.org/10.1172/JCI112798)

20 Rehnmark S, Bianco AC, Kieffer JD \& Silva JE. Transcriptional and posttranscriptional mechanisms in uncoupling protein mRNA response to cold. American Journal of Physiology 1992262 E58-E67. (https://doi.org/10.1152/ajpendo.1992.262.1.E58)

21 Hoefig CS, Harder L, Oelkrug R, Meusel M, Vennström B, Brabant G \& Mittag J. Thermoregulatory and cardiovascular consequences of a transient thyrotoxicosis and recovery in male mice. Endocrinology 2016157 2957-2967. (https://doi.org/10.1210/ en.2016-1095)

22 Johann K, Cremer AL, Fischer AW, Heine M, Pensado ER, Resch J, Nock S, Virtue S, Harder L, Oelkrug R, et al. Thyroid-hormoneinduced browning of white adipose tissue does not contribute to thermogenesis and glucose consumption. Cell Reports 2019273385. e3-3400.e3. (https://doi.org/10.1016/j.celrep.2019.05.054)

23 Rabelo R, Schifman A, Rubio A, Sheng X \& Silva JE. Delineation of thyroid hormone-responsive sequences within a critical enhancer in the rat uncoupling protein gene. Endocrinology 1995136 1003-1013. (https://doi.org/10.1210/endo.136.3.7867554)

24 Silva JE \& Larsen PR. Adrenergic activation of triiodothyronine production in brown adipose tissue. Nature 1983305 712-713. (https://doi.org/10.1038/305712a0)

25 St Germain DL, Galton VA \& Miniereview HA. Defining the roles of the lodothyronine deiodinases: current concepts and challenges. Endocrinology 2009150 1097-1107. (https://doi.org/10.1210/ en.2008-1588) https://ec.bioscientifica.com https://doi.org/10.1530/EC-20-0562
(C) 2021 The authors Published by Bioscientifica Ltd
This work is licensed under a Creative Commons Attribution-NonCommercial-NoDerivatives 4.0 enternationab ficense.ifica . com at 04/26/2023 01:29:42PM 
26 Schneider MJ, Fiering SN, Pallud SE, Parlow AF, St Germain DL $\&$ Galton VA. Targeted disruption of the type 2 selenodeiodinase gene $\left(\mathrm{DiO}_{2}\right)$ results in a phenotype of pituitary resistance to T4. Molecular Endocrinology 200115 2137-2148. (https://doi.org/10.1210/ mend.15.12.0740)

27 De Jesus LA, Carvalho SD, Ribeiro MO, Schneider M, Kim SW, Harney JW, Larsen PR \& Bianco AC. The type 2 iodothyronine deiodinase is essential for adaptive thermogenesis in brown adipose tissue. Journal of Clinical Investigation 2001108 1379-1385. (https:// doi.org/10.1172/JCI13803)

28 Christoffolete MA, Linardi CCG, De Jesus LA, Ebina KN, Carvalho SD, Ribeiro MO, Rabelo R, Curcio C, Martins L, Kimura ET, et al. Mice with targeted disruption of the $\mathrm{DiO}_{2}$ gene have coldinduced overexpression of the uncoupling protein 1 gene but fail to increase brown adipose tissue lipogenesis and adaptive thermogenesis. Diabetes 200453 577-584. (https://doi.org/10.2337/ diabetes.53.3.577)

29 Reitert RJ, Klaus S, Ebbinghaus C, Heldmaier G, Redlin U, Ricquier D, Vaughan MK \& Steinlechner S. Inhibition of 5'-deiodination of thyroxine suppresses the cold-induced increase in brown adipose tissue messenger ribonucleic acid for mitochondrial uncoupling protein without influencing lipoprotein lipase activity. Endocrinology 1990126 2550-2554. (https://doi.org/10.1210/endo-126-5-2550)

30 Bianco AC, Carvalho SD, Carvalho CRF, Rabelo R \& Moriscot AS. Thyroxine 5'-deiodination mediates norepinephrine induced lipogenesis in dispersed brown adipocytes. Endocrinology 1998139 571-578. (https://doi.org/10.1210/endo.139.2.5737)

31 Obregón MJ. Adipose tissues and thyroid hormones. Frontiers in Physiology 20145 479. (https://doi.org/10.3389/fphys.2014.00479)

32 Ribeiro MO, Lebrun FLAS, Christoffolete MA, Branco M, Crescenzi A, Carvalho SD, Negrão N \& Bianco AC. Evidence of UCP1-independent regulation of norepinephrine-induced thermogenesis in brown fat. American Journal of Physiology: Endocrinology and Metabolism 2000279 E314-E322. (https://doi. org/10.1152/ajpendo.2000.279.2.E314)

33 Kennedy DR, Hammond RP \& Hamolsky MW. Thyroid cold acclimation influences on norepinephrine metabolism in brown fat. American Journal of Physiology 1977232 E565-E569. (https://doi. org/10.1152/ajpendo.1977.232.6.E565)

34 Weiner J, Kranz M, Klöting N, Kunath A, Steinhoff K, Rijntjes E, Köhrle J, Zeisig V, Hankir M, Gebhardt C, et al. Thyroid hormone status defines brown adipose tissue activity and browning of white adipose tissues in mice. Scientific Reports 20166 38124. (https://doi. org/10.1038/srep38124)

35 Lavado-Autric R, Calvo RM, Martinez de Mena R, Morreale de Escobar G \& Obregón MJ. Deiodinase activities in thyroids and tissues of iodine-deficient female rats. Endocrinology 2013154 529-536. (https://doi.org/10.1210/en.2012)

36 Ueta CB, Olivares EL \& Bianco AC. Responsiveness to thyroid hormone and to ambient temperature underlies differences between brown adipose tissue and skeletal muscle thermogenesis in a mouse model of diet-induced obesity. Endocrinology 2011152 3571-3581. (https://doi.org/10.1210/en.2011-1066)

37 Branco M, Ribeiro M, Negrão N \& Bianco AC. 3,5,3'-Triiodothyronine actively stimulates UCP in brown fat under minimal sympathetic activity. American Journal of Physiology 1999276 E179-E187. (https:// doi.org/10.1152/ajpendo.1999.276.1.E179)

38 Rubio A, Raasmaja A \& Silva JE. Thyroid hormone and norepinephrine signaling in brown adipose tissue. II: differential effects of thyroid hormone on $\beta 3$-adrenergic receptors in brown and white adipose tissue. Endocrinology 1995136 3277-3284. (https://doi. org/10.1210/endo.136.8.7628361)

39 Mittag J. More than fever - novel concepts in the regulation of body temperature by thyroid hormones. Experimental and Clinical Endocrinology and Diabetes 2020128 428-431. (https://doi. org/10.1055/a-1014-2510)
40 Yen PM. Physiological and molecular basis of thyroid hormone action. Physiological Reviews 200181 1097-1142. (https://doi. org/10.1152/physrev.2001.81.3.1097)

41 Forrest D, Erway LC, Ng L, Altschuler R \& Curran T. Thyroid hormone receptor $\beta$ is essential for development of auditory function. Nature Genetics 199613 354-357. (https://doi.org/10.1038/ ng0796-354)

42 Hernández A \& Obregón MJ. Presence and mRNA expression of T3 receptors in differentiating rat brown adipocytes. Molecular and Cellular Endocrinology 1996121 37-46. (https://doi. org/10.1016/0303-7207(96)03849-X)

43 Ribeiro MO, Carvalho SD, Schultz JJ, Chiellini G, Scanlan TS, Bianco AC \& Brent GA. Thyroid hormone-sympathetic interaction and adaptive thermogenesis are thyroid hormone receptor isoformspecific. Journal of Clinical Investigation 2001108 97-105. (https:// doi.org/10.1172/JCI200112584)

44 Ribeiro MO, Bianco SDC, Kaneshige M, Schultz JJ, Cheng SY, Bianco AC \& Brent GA. Expression of uncoupling protein 1 in mouse brown adipose tissue is thyroid hormone receptor- $\beta$ isoform specific and required for adaptive thermogenesis. Endocrinology $2010 \mathbf{1 5 1}$ 432-440. (https://doi.org/10.1210/en.2009-0667)

45 Marrif H, Schifman A, Stepanyan Z, Gillis MA, Calderone A, Weiss RE, Samarut J \& Silva JE. Temperature homeostasis in transgenic mice lacking thyroid hormone receptor- $\alpha$ gene products. Endocrinology 2005146 2872-2884. (https://doi.org/10.1210/en.2004-1544)

46 Sjögren M, Alkemade A, Mittag J, Nordström K, Katz A, Rozell B, Westerblad H, Arner A \& Vennström B. Hypermetabolism in mice caused by the central action of an unliganded thyroid hormone receptor $\alpha 1$. EMBO Journal 200726 4535-4545. (https://doi. org/10.1038/sj.emboj.7601882)

47 Beaven MA, Costa E \& Brodie BB. The turnover of norepinephrine in thyrotoxic and nonthyrotoxic mice. Life Sciences 19634 241-246. (https://doi.org/10.1016/0024-3205(63)90004-3)

48 Coulombe P, Dussault JH, Letarte J \& Simard SJ. Catecholamines metabolism in thyroid diseases. I. Epinephrine secretion rate in hyperthyroidism and hypothyroidism. Journal of Clinical Endocrinology and Metabolism 197642 125-131. (https://doi. org/10.1210/jcem-42-1-125)

49 Coulombe P, Dussault JH \& Walker P. Catecholamine metabolism in thyroid disease. II. Norepinephrine secretion rate in hyperthyroidism and hypothyroidism. Journal of Clinical Endocrinology and Metabolism 197744 1185-1189. (https://doi. org/10.1210/jcem-44-6-1185)

50 Silva JE. Thermogenic mechanisms and their hormonal regulation. Physiological Reviews 200686 435-464. (https://doi.org/10.1152/ physrev.00009.2005)

51 Nedergaard J, Dicker A \& Cannon B. The Interaction between thyroid and brown-fat thermogenesis. Central or peripheral effects? Annals of the New York Academy of Sciences 1997813 712-717. (https://doi. org/10.1111/j.1749-6632.1997.tb51772.x)

52 Katz LS, Xu S, Ge K, Scott DK \& Gershengorn MC. T3 and glucose coordinately stimulate ChREBP-mediated Ucp1 expression in brown adipocytes from male mice. Endocrinology 2018159 557-569. (https://doi.org/10.1210/en.2017-00579)

53 López M, Varela L, Vázquez MJ, Rodríguez-Cuenca S, González CR, Velagapudi VR, Morgan DA, Schoenmakers E, Agassandian K, Lage R, et al. Hypothalamic AMPK and fatty acid metabolism mediate thyroid regulation of energy balance. Nature Medicine 201016 1001-1008. (https://doi.org/10.1038/nm.2207)

54 López M, Alvarez CV, Nogueiras R \& Diéguez C. Energy balance regulation by thyroid hormones at central level. Trends in Molecular Medicine 201319 418-427. (https://doi.org/10.1016/j. molmed.2013.04.004)

55 Alvarez-Crespo M, Csikasz RI, Martínez-Sánchez N, Diéguez C, Cannon B, Nedergaard J \& López M. Essential role of UCP1 modulating the central effects of thyroid hormones on energy 
balance. Molecular Metabolism 20165 271-282. (https://doi. org/10.1016/j.molmet.2016.01.008)

56 Martínez-Sánchez N, Seoane-Collazo P, Contreras C, Varela L, Villarroya J, Rial-Pensado E, Buqué X, Aurrekoetxea I, Delgado TC, Vázquez-Martínez R, et al. Hypothalamic AMPK-ER stress-JNK1 axis mediates the central actions of thyroid hormones on energy balance. Cell Metabolism 201726 212.e12-229.e12. (https://doi.org/10.1016/j. cmet.2017.06.014)

57 Hameed S, Patterson M, Dhillo WS, Rahman SA, Ma Y, Holton C, Gogakos A, Yeo GSH, Lam BYH, Polex-Wolf J, et al. Thyroid hormone receptor beta in the ventromedial hypothalamus is essential for the physiological regulation of food intake and body weight. Cell Reports 201719 2202-2209. (https://doi.org/10.1016/j. celrep.2017.05.066)

58 Wallis K, Dudazy S, Van Hogerlinden M, Nordström K, Mittag J \& Vennström B. The thyroid hormone receptor $\alpha 1$ protein is expressed in embryonic postmitotic neurons and persists in most adult neurons. Molecular Endocrinology 201024 1904-1916. (https://doi. org/10.1210/me.2010-0175)

59 Minakhina S, Bansal S, Zhang A, Brotherton M, Janodia R, De Oliveira V, Tadepalli S \& Wondisford FE. A direct comparison of thyroid hormone receptor protein levels in mice provides unexpected insights into thyroid hormone action. Thyroid 202030 1193-1204. (https://doi.org/10.1089/thy.2019.0763)

60 Mayerl S, Müller J, Bauer R, Richert S, Kassmann CM, Darras VM, Buder K, Boelen A, Visser TJ \& Heuer H. Transporters MCT8 and OATP1C1 maintain murine brain thyroid hormone homeostasis. Journal of Clinical Investigation 2014124 1987-1999. (https://doi. org/10.1172/JCI70324)

61 Herrmann B, Harder L, Oelkrug R, Chen J, Gachkar S, Nock S, Resch J, Korkowski M, Heuer H \& Mittag J. Central hypothyroidism impairs heart rate stability and prevents thyroid hormone-induced cardiac hypertrophy and pyrexia. Thyroid 202030 1205-1216. (https://doi.org/10.1089/thy.2019.0705)

62 Dittner C, Lindsund E, Cannon B \& Nedergaard J. At thermoneutrality, acute thyroxine-induced thermogenesis and pyrexia are independent of UCP1. Molecular Metabolism 201925 20-34. (https://doi.org/10.1016/j.molmet.2019.05.005)

63 Nicolaisen TS, Klein AB, Dmytriyeva O, Lund J, Ingerslev LR, Fritzen AM, Carl CS, Lundsgaard AM, Frost M, Ma T, et al. Thyroid hormone receptor $\alpha$ in skeletal muscle is essential for T3-mediated increase in energy expenditure. FASEB Journal 202034 15480-15491. (https://doi.org/10.1096/fj.202001258RR)

64 Kaspari RR, Reyna-Neyra A, Jung L, Torres-Manzo AP, Hirabara SM \& Carrasco N. The paradoxical lean phenotype of hypothyroid mice is marked by increased adaptive thermogenesis in the skeletal muscle. PNAS 2020117 22544-22551. (https://doi.org/10.1073/ pnas.2008919117)

65 Hayat NQ, Nadir S \& Muneera MJ. The effect of hypothyroidism on the body weight of adult albino Wistar rats. Journal of Rawalpindi Medical College 201620 147-149.

66 Hernández A, Martinez de Mena RM, Martin E \& Obregón MJ. Differences in the response of UCP1 mRNA to hormonal stimulation between rat and mouse primary cultures of brown adipocytes. Cellular Physiology and Biochemistry 201128 969-980. (https://doi. org/10.1159/000335810)

67 Nedergaard J \& Cannon B. UCP1 mRNA does not produce heat. Biochimica et Biophysica Acta 20131831 943-949. (https://doi. org/10.1016/j.bbalip.2013.01.009)

68 Lin JZ, Martagón AJ, Cimini SL, Gonzalez DD, Tinkey DW, Biter A, Baxter JD, Webb P, Gustafsson JÅ, Hartig SM, et al. Pharmacological activation of thyroid hormone receptors elicits a functional conversion of white to brown fat. Cell Reports 201513 1528-1537. (https://doi.org/10.1016/j.celrep.2015.10.022)

69 Ikeda K, Kang Q, Yoneshiro T, Camporez JP, Maki H, Homma M, Shinoda K, Chen Y, Lu X, Maretich P, et al. UCP1-independent signaling involving SERCA2b-mediated calcium cycling regulates beige fat thermogenesis and systemic glucose homeostasis. Nature Medicine 201723 1454-1465. (https://doi.org/10.1038/nm.4429)

70 Kazak L, Chouchani ET, Jedrychowski MP, Erickson BK, Shinoda K, Cohen P, Vetrivelan R, Lu GZ, Laznik-Bogoslavski D, Hasenfuss SC, et al. A creatine-driven substrate cycle enhances energy expenditure and thermogenesis in beige fat. Cell 2015163 643-655. (https://doi. org/10.1016/j.cell.2015.09.035)

71 Warner A, Rahman A, Solsjö P, Gottschling K, Davis B, Vennström B, Arner A \& Mittag J. Inappropriate heat dissipation ignites brown fat thermogenesis in mice with a mutant thyroid hormone receptor

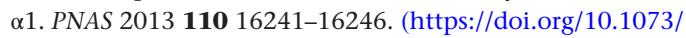
pnas.1310300110)

72 Warner A \& Mittag J. Brown fat and vascular heat dissipation: the new cautionary tail. Adipocyte 20143 221-223. (https://doi. org/10.4161/adip.28815)

Received in final form 7 January 2021

Accepted 20 January 2021

Accepted Manuscript published online 26 January 2021 https://ec.bioscientifica.com https://doi.org/10.1530/EC-20-0562 (c) 2021 The authors Published by Bioscientifica Ltd
This work is licensed under a Creative Commons Attribution-NonCommercial-NoDerivatives 4.0 enternationab dicense.ifica . com at 04/26/2023 01:29:42PM 